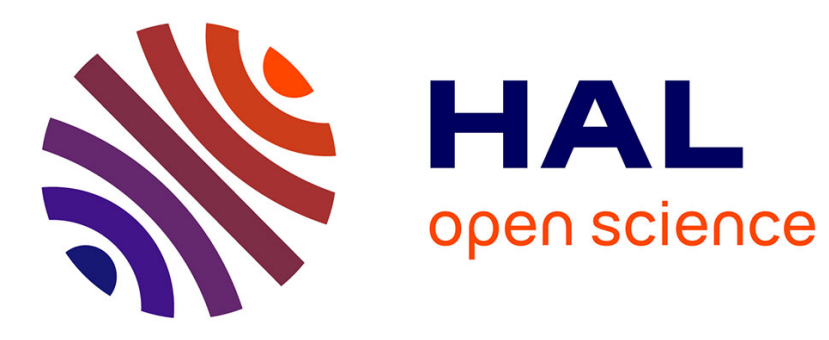

\title{
Intermolecular interaction in [C6H10N3]2[CoCl4] complex: Synthesis, XRD/HSA relation, spectral and catecholase catalytic analysis
}

Abderrahim Titi, Ismail Warad, Monique Tillard, Rachid Touzani, Mouslim Messali, Mohamed El Kodadi, Driss Eddike, Abdelkader Zarrouk

\section{To cite this version:}

Abderrahim Titi, Ismail Warad, Monique Tillard, Rachid Touzani, Mouslim Messali, et al.. Intermolecular interaction in [C6H10N3]2[CoCl4] complex: Synthesis, XRD/HSA relation, spectral and catecholase catalytic analysis. Journal of Molecular Structure, 2020, 1217, pp.128422. 10.1016/j.molstruc.2020.128422 . hal-02887895

\section{HAL Id: hal-02887895 https://hal.science/hal-02887895}

Submitted on 23 Nov 2020

HAL is a multi-disciplinary open access archive for the deposit and dissemination of scientific research documents, whether they are published or not. The documents may come from teaching and research institutions in France or abroad, or from public or private research centers.
L'archive ouverte pluridisciplinaire HAL, est destinée au dépôt et à la diffusion de documents scientifiques de niveau recherche, publiés ou non, émanant des établissements d'enseignement et de recherche français ou étrangers, des laboratoires publics ou privés. 


\title{
Intermolecular Interactions in $\left[\mathrm{C}_{6} \mathrm{H}_{10} \mathrm{~N}_{3}\right]_{2}\left[\mathrm{CoCl}_{4}\right]$ complex; Synthesis, $\mathrm{XRD} / \mathrm{HSA}$ relation, spectral and Catecholase catalytic analysis
}

\author{
Abderrahim Titi a, ${ }^{a}$, Ismail Warad ${ }^{\mathrm{b},{ }^{*}}$, Monique Tillard ${ }^{\mathrm{c}}$, Rachid Touzani ${ }^{\mathrm{a}}$, Mouslim Messali ${ }^{\mathrm{d}}$ \\ Mohamed El Kodadi ${ }^{\mathrm{a}, \mathrm{e}}$, Driss Eddike ${ }^{\mathrm{f}}$, Abdelkader Zarrouk ${ }^{\mathrm{g}}$ \\ ${ }^{a}$ Laboratory of Applied and Environmental Chemistry, Mohammed first University, Oujda, Morocco \\ (LCAE). \\ ${ }^{b}$ Department of Chemistry and Earth Sciences, PO Box 2713, Qatar University, Doha, Qatar \\ ${ }^{c}$ ICGM, Université de Montpellier, CNRS, ENSCM, Montpellier, France \\ 'Department of Chemistry, Taibah University, 30002 Al-Madina Al-Mounawara, SaudiArabia. \\ ${ }^{e}$ CRMEF Oriental, Centre Régional des Métiers de l'Education et de Formation Oujda, Morocco \\ ${ }^{f}$ Laboratory of Inorganic Solid State Chemistry, Mohammed first University, Oujda, Morocco. \\ ${ }^{g}$ Laboratory of Materials, Nanotechnology and Environment, Faculty of Sciences, Mohammed V \\ University, Av. Ibn Battouta, Box 1014, Agdal-Rabat, Morocoo
}

\begin{abstract}
Complex of bis(6-amino-2,4-dimethylpyrimidin-1-ium) tetrachloridecobaltate(II) $\left[\mathrm{C}_{6} \mathrm{H}_{10} \mathrm{~N}_{3}\right]_{2}\left[\mathrm{CoCl}_{4}\right]$ was synthesized and characterized using several physicochemical surveys as FT-IR, 1H \& 13C-NMR, Hirshfeld surface (HSA) and XRD-diffraction analysis. The XRD and HSA quantified a significant contribution of non-covalent $\mathrm{H}$-bonds interactions in lattice to build an ionic form of the $\left[\mathrm{C}_{6} \mathrm{H}_{10} \mathrm{~N}_{3}\right]_{2}\left[\mathrm{CoCl}_{4}\right]$ complex. The molecular arrangement is qualified for the desired complex as an alternation of inorganic and organic species, the organic $\mathrm{C}_{6} \mathrm{H}_{10} \mathrm{~N}_{3}$ cationic ligand and inorganic $\left[\mathrm{CoCl}_{4}\right]^{2-}$ tetrahedral anionic metal center connected together via several short interactions like $-\mathrm{HN}-\mathrm{H} \ldots \mathrm{Cl}$, Nring-H+...Cl and Cring-H...Cl Hbonds interactions. The complex was tested as a catalyst for the oxidation reaction in methanol from 3,5-ditertiarybutylcatechol to 3,5 ditertiarybutylquinone. The $\left[\mathrm{C}_{6} \mathrm{H}_{10} \mathrm{~N}_{3}\right]_{2}\left[\mathrm{CoCl}_{4}\right]$ complex displays a good catalytic activity in aerobic condition, with a reaction rate Vmax $=10.11 \times 10$ $4 \mathrm{M} \cdot \mathrm{L}^{-1} \cdot \mathrm{h}^{-1}$ and key kinetics parameters $\mathrm{KM}=0.12 \mathrm{M}$ and $\mathrm{kcat}=84.08 \mathrm{M}^{-1} \cdot \mathrm{h}^{-1}$.
\end{abstract}

Keywords: Cobalt(II); Crystal structure; HSA; Catecholase activity. 


\section{Introduction}

Organic and inorganic hybrids material are highly wanted compounds due to their broad range of applicable properties, their exceptional structural and amazing composition diversity [1]. Therefore, the structures of the inorganic anion and organic cations reflected several unique properties like optical, electrical, electroluminescence and magnetic [1-6]. Currently, hybrid organic-inorganic crystalline solids containing anionic metal complexes and organic cations have been developed for their hydrogen bonding like N-H...X connections with halides of the metal center to build and design the crystal structure lattice of hybrid material for structural analysis [7-9]. However, studies dilling with such kind of material is still limited.

Cobalt-organic hybrid material complexes are one of the most significant materials in inorganic chemistry, its advantages include good tunable bandgap, electric mobility, thermal stability, magnetic properties, and structural varieties served it to be very good catalysts [1-6]. Even after the discovery of the famous hydroformylation catalytic process by Otto Roelen, many other catalytic applications have been promoted [10-15]. Design of cobalt-organic hybrid material that can activate molecular oxygen stile a challenge to predict super-oxidation catalysts (SOC) [16]. Synthetic model studies on the reactivity of cobalt complexes towards Catecholase oxidation processes, both implicate structural and electronic parts as being accountable for the catalytic activity [16-18].

Considering the attributes and attractive the of tetrachlorocobaltate(II), herein, we report on the preparation of a new $\left[\mathrm{C}_{6} \mathrm{H}_{10} \mathrm{~N}_{3}\right]_{2}\left[\mathrm{CoCl}_{4}\right]$ complex based on cobalt(II) and (6-amino-2,4dimethylpyrimidin-1-ium) ligand, the intermolecular interactions in the structure was compared by XRD and HAS, physicochemical and oxidation properties of the complex were also figure out under RT conditions.

\section{Experimental}

\subsection{Materials and physical measurements}

All the chemicals reagents and solvents were commercial available and used as received. IR were recorded at RT using a Perkin Elmer FT- IR spectrometer in the 4000-500 $\mathrm{cm}^{-1}$ frequency range. ${ }^{1} \mathrm{H}$ and ${ }^{13} \mathrm{C}$ NMR were recorded on a BRUKER equipment at $400 \mathrm{MHz}$ for ${ }^{1} \mathrm{H}$ and $100 \mathrm{MHz}$ for ${ }^{13} \mathrm{C}$. Spin resonances are presented as chemical shifts $(\delta)$ in ppm and referenced as follow to the residual peak of the solvent employed as an internal standard: DMSO-d ${ }_{6} 2.50$ ppm ( ${ }^{1} \mathrm{H}$ NMR $), 39.9$ ppm $\left({ }^{13} \mathrm{C} \mathrm{NMR}\right)$. The UV - Vis spectra were recorded on 
an UV-1280 Shimadzu spectrometer. The Hirschfeld surfaces have been computed using the Crystal Explorer 3.1 program [19].

\subsection{Synthesis of $\left[\mathrm{C}_{12} \mathrm{H}_{20} \mathrm{~N}_{6} \mathrm{CoCl}_{4}\right]$}

A volume of $10 \mathrm{~mL}$ of 2,6-dimethylpyrimidin-4-amine $(50 \mathrm{mg}, 0.41 \mathrm{mmol})$ in solution in ethanol) was treated with $10 \mathrm{~mL}$ of solution of $\mathrm{CoCl}_{2} \cdot 6 \mathrm{H}_{2} \mathrm{O}(96.5 \mathrm{mg}, 0.41 \mathrm{mmol})$ dissolved in ethanol, (35.6 $\mathrm{mg}, 0.82 \mathrm{mmol})$ of $\mathrm{HCl}$ was added to the reaction mixture (Scheme 1). Precipitation of a blue powder occurred while stirring at room temperature for $24 \mathrm{~h}$. The blue powder was filtered and washed with $\mathrm{EtOH}(30 \mathrm{~mL})$, followed by $\mathrm{Et}_{2} \mathrm{O}(30 \mathrm{~mL})$ to give the blue solid (1.3g, 70\%). Recrystallization of the crude product from a solvent pair $\left(\mathrm{CH}_{3}\right)_{2} \mathrm{CO} / \mathrm{Et}_{2} \mathrm{O}$ gave blue crystals $(1.2 \mathrm{~g}, 64.6 \%) .{ }^{1} \mathrm{H}$ NMR (DMSO-d6, 400MHz): $\delta=2.13\left(\mathrm{~s}, \mathrm{CH}_{3}\right), 2.25$ (s, $\left.\mathrm{CH}_{3}\right), 6.06(\mathrm{~s}, \mathrm{C}-\mathrm{H}), 6.63\left(\mathrm{~s}, \mathrm{NH}_{2}\right) .{ }^{13} \mathrm{C} \mathrm{NMR}$ (DMSO-d6, $\left.100 \mathrm{MHz}\right): \delta=23.71\left(\mathrm{CH}_{3}\right), 25.72$ $\left(\mathrm{CH}_{3}\right), 100.53(\mathrm{C}-\mathrm{H}), 164.29(\mathrm{C}), 164.38$ (C), 166.99 (C). Selected IR peaks of the desired complex $v=3350(\mathrm{~N}-\mathrm{H}), 2934(\mathrm{C}-\mathrm{H}), 1678(\mathrm{C}=\mathrm{N}), 1490(\mathrm{C}=\mathrm{C}), 1436(\mathrm{C}-\mathrm{H}), 1358(\mathrm{~N}=\mathrm{N})$, 1018(C-N), 720(C-H), $520(\mathrm{Co}-\mathrm{Cl}) \mathrm{cm}^{-1}$.
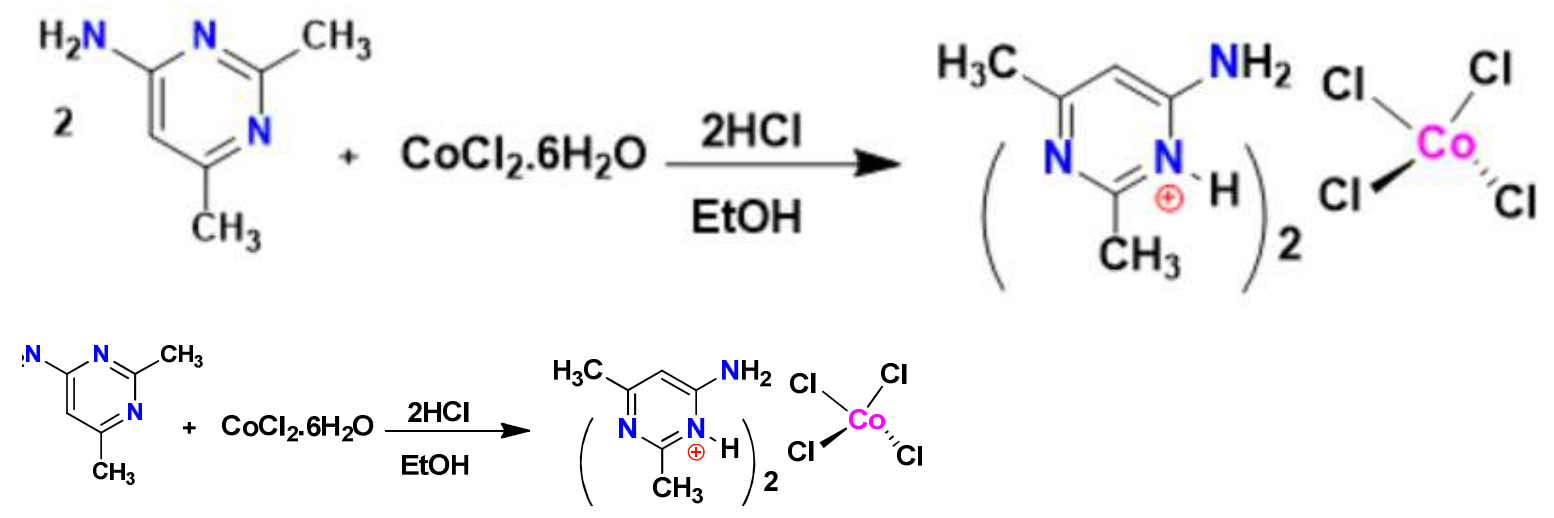

Scheme1: Synthesis of the complex $\mathrm{CoCl}_{4} \mathrm{LH}$.

\subsection{X-ray crystal structure}

A blue platelet was selected under a stereo microscope with a polarizing filter to be a single crystal suitable for diffracted intensities recording. Data were measured at room temperature on a Bruker D8 Venture 4-circle diffractometer equipped with a Incoatec $\mathrm{I} \mu \mathrm{S} 3.0 \mathrm{Mo}$ microsource $(110 \mu \mathrm{m}$ beam, K $\alpha$ radiation $\lambda=0.71073 \AA)$ and a Photon II CPAD detector. Cell refinement, data reduction and Lorentz-polarization corrections were performed using the Apex 
software suite [20] and reflections were corrected for absorption effects (multi-scan SADABS). The structure was solved and refined by full-matrix least-squares on $\mathrm{F}^{2}$ using the SHELX programs $[21,22]$. Positional and anisotropic displacement parameters were refined for all non$\mathrm{H}$ atoms. The $\mathrm{H}$ atoms were detected in the final Fourier difference and, with the exception of the freely refined amine and ammonium $\mathrm{H}$ atoms, were treated using AFIX instructions with displacement parameters equal to 1.2 times $\left(1.5\right.$ for $\left.-\mathrm{CH}_{3}\right)$ the $\mathrm{U}_{\text {eq }}$ of the parent atom. The main crystal data and refinement parameters are given in Table 1.

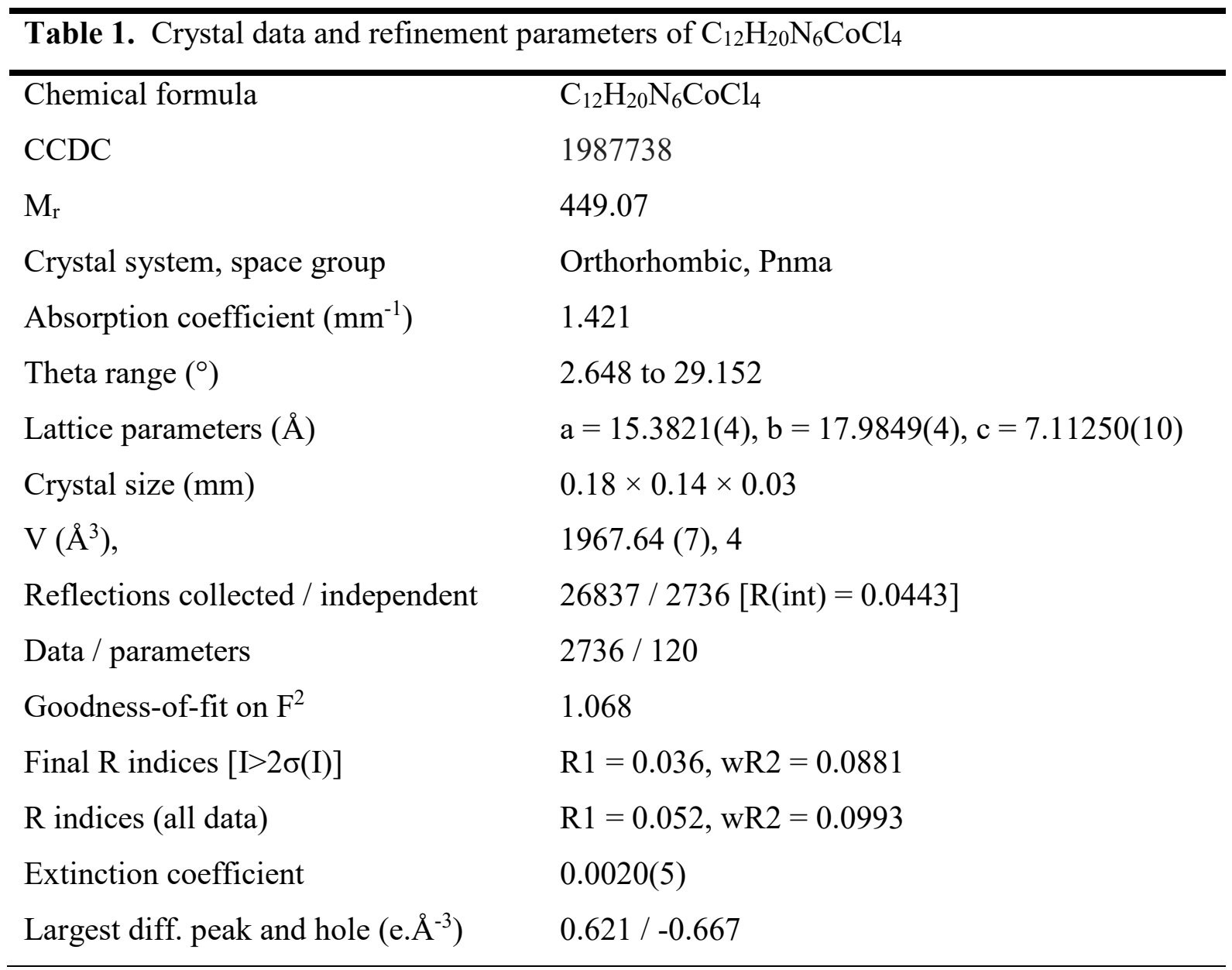

\section{Results and discussion}

\subsection{Synthesis, $C H N-E A, I R, U V$-vis. and NMR analysis}

The prepared of bis(6-amino-2,4-dimethylpyrimidin-1-ium) tetrachloridecobaltate(IV) $\left[\mathrm{C}_{6} \mathrm{H}_{10} \mathrm{~N}_{3}\right]_{2}\left[\mathrm{CoCl}_{4}\right]$ Complex was made available by mixing of [1:1] $\mathrm{CoCl}_{2} .4 \mathrm{H}_{2} \mathrm{O}$ with of 6amino-2,4-dimethylpyrimidin-1-ium in the presence of $\mathrm{HCl}$ dissolved in ethanol. The blue color precipitate indicated the formation of the desired complex with good yield after one day 
of stirring under open RT condition. The complex is water-soluble, poor insolubility in ROH and insoluble in hexane or ethers which supported the complex $\left[\mathrm{C}_{6} \mathrm{H}_{10} \mathrm{~N}_{3}\right]_{2}\left[\mathrm{CoCl}_{4}\right]$ salty nature.

The composition of the complex was confirmed using CHN-elemental analysis, the calculated atomic percentage of the $\mathrm{C}, 32.09 ; \mathrm{H}, 4.49$ and $\mathrm{N}, 13.12 \%$ from $\mathrm{C} 12 \mathrm{H} 20 \mathrm{Cl}$ CoN6 formula and found experimentally as $\mathrm{C}, 32.02 ; \mathrm{H}, 4.20$ and N, 13.16\% which is with agree with the general $\left[\mathrm{C}_{6} \mathrm{H}_{10} \mathrm{~N}_{3}\right]_{2}\left[\mathrm{CoCl}_{4}\right]$ formula.

The reaction of $\mathrm{CoCl}_{2} \cdot 4 \mathrm{H}_{2} \mathrm{O}$ with 6-amino-2,4-dimethylpyrimidin-1-ium ligand to produce $\left[\mathrm{C}_{6} \mathrm{H}_{10} \mathrm{~N}_{3}\right]_{2}\left[\mathrm{CoCl}_{4}\right]$ complex was monitored by IR. IR spectra of the ligand and its complex are illustrated in Fig. 1.

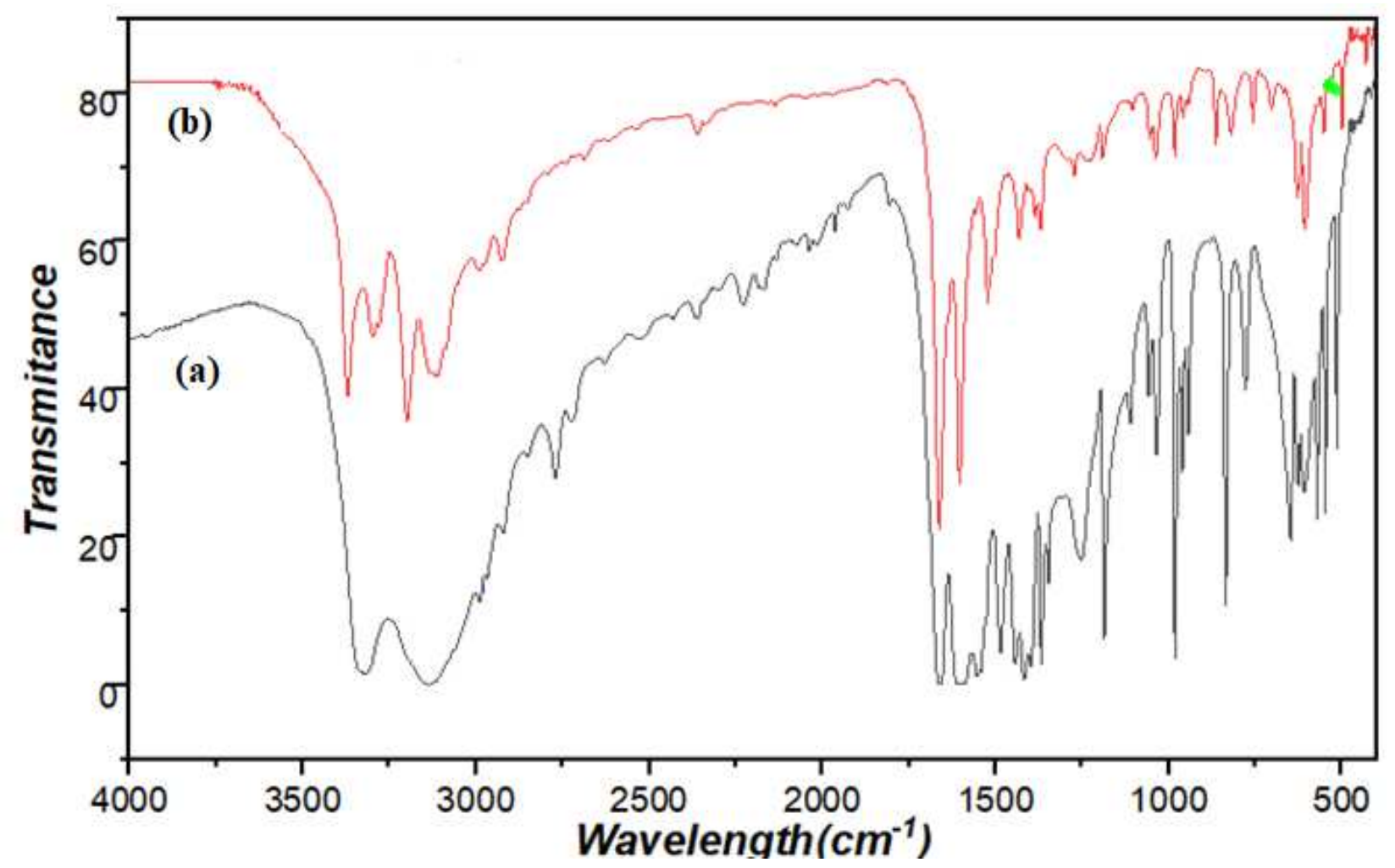

Fig. 1. FT-IR spectra of free ligand (a) and the $\left[\mathrm{C}_{6} \mathrm{H}_{10} \mathrm{~N}_{3}\right]_{2}\left[\mathrm{CoCl}_{4}\right]$ complex (b).

Several stretching vibrations, like N-H, $\mathrm{Cph}_{\mathrm{ph}}-\mathrm{H}, \mathrm{C}_{\mathrm{Me}}-\mathrm{H}, \mathrm{C}=\mathrm{N}, \mathrm{C}-\mathrm{C}, \mathrm{C}=\mathrm{C}$ and $\mathrm{Co}-\mathrm{Cl}$ [23] were recorded to their expected chemical shifts (experimental section). The sharp and broad band at $3350 \mathrm{~cm}^{-1}$ for $\mathrm{N}-\mathrm{H}$ in the free ligand did not shift to lower chemical shift by the complexation with the Co center which indicating no Co-N bond formation. Moreover, no new 
broad signal $\sim 500 \mathrm{~cm}^{-1}$ was appearance in the spectrum of the complex supporting the $\left[\mathrm{C}_{6} \mathrm{H}_{10} \mathrm{~N}_{3}\right]_{2}\left[\mathrm{CoCl}_{4}\right]$ salty nature of the desired complex [23-28].

The UV-visible electron transfer spectra of the 1x10-4 $\mathrm{M}$ of the desired $\left[\mathrm{C}_{6} \mathrm{H}_{10} \mathrm{~N}_{3}\right]_{2}\left[\mathrm{CoCl}_{4}\right]$ complex in DMSO at RT is illustrated in Fig. 2. The UV band with $\chi$ max at $280 \mathrm{~nm}$ is sited to the $\pi$ to $\pi^{*}$ e-transition in the aromatic group of the ligand. Moreover, maximum absorption bands at $\chi$ 's $350-420 \mathrm{~nm}$ in the visible area are attributed to $d-d$ etransition indicating the $\left[\mathrm{CoCl}_{4}\right]^{-2}$ with Td geometry around cobalt atom [23-28].

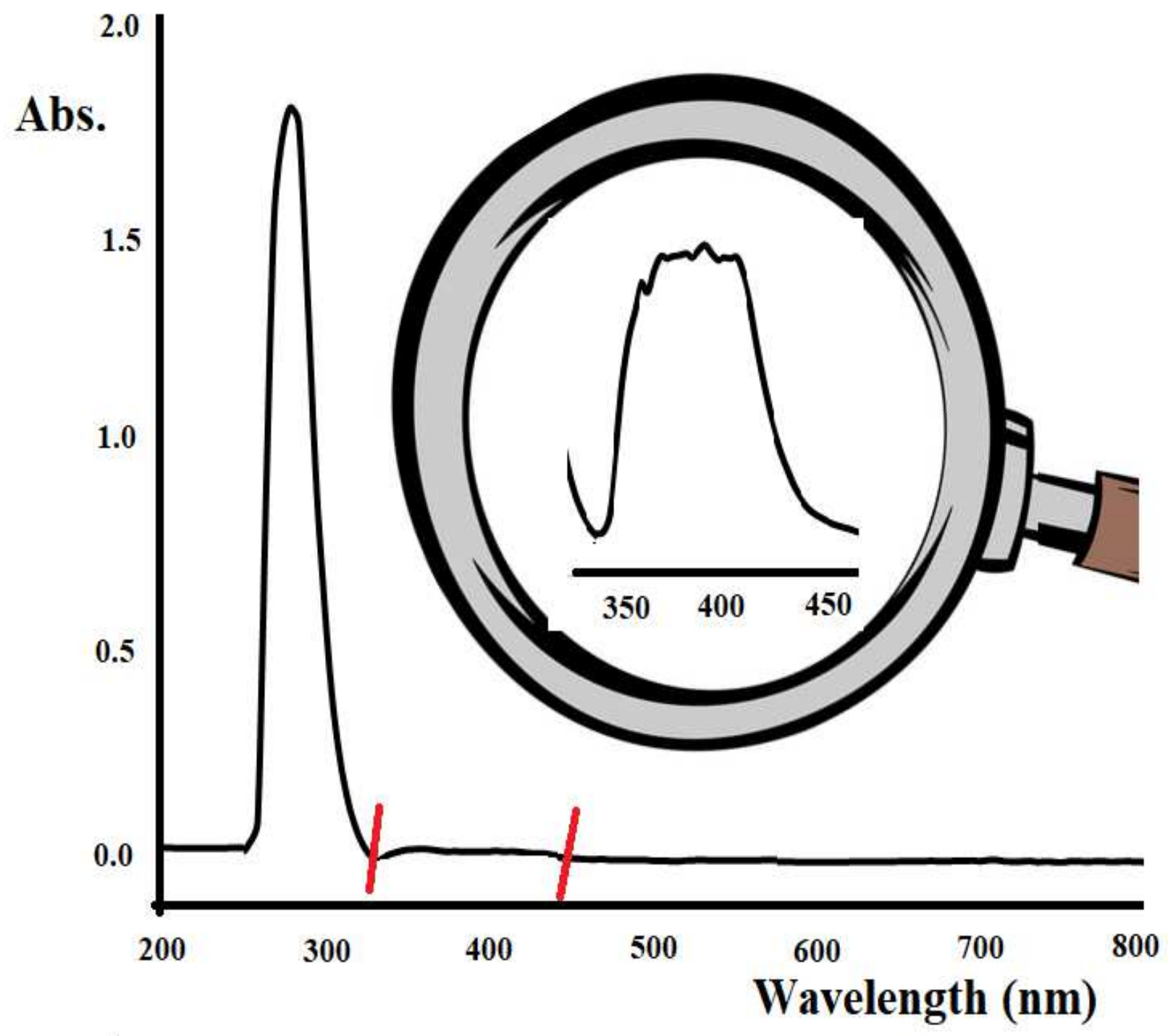

Fig. 2. UV- Visible of $\left[\mathrm{C}_{6} \mathrm{H}_{10} \mathrm{~N}_{3}\right]_{2}\left[\mathrm{CoCl}_{4}\right]$ complex 
The ${ }^{1} \mathrm{H}$ and ${ }^{13} \mathrm{C}-\mathrm{NMR}$ spectra of $\left[\mathrm{C}_{6} \mathrm{H}_{10} \mathrm{~N}_{3}\right]_{2}\left[\mathrm{CoCl}_{4}\right]$ complex dissolved in DMSO-d6 reflected the complex as paramagnetic compound since the Co is with +2 , therefore the electronic configuration of the tetrahedral Co center will be $4 s^{0} 3 d^{7}$ with eg $g^{4}$ and $t 1 g^{3} d$-splitting.

Two types of protons consistent with the structure formula detected by XRD were recorded as in Fig.3. 1H NMR two signal belong to $6 \mathrm{H}$ of the $\mathrm{CH} 3$ at $\delta 2.13$ and $2.25 \mathrm{ppm}$, one signal at $6.06 \mathrm{ppm}$ cited to Cring-H and the broad signal at $\delta 8.3$ cited to $2 \mathrm{H}$ of $\mathrm{NH} 2$ (Fig.3a). The $\mathrm{N}-\mathrm{H}+$ protons signals did not appear due to D-exchanged with the D2O.

13C-NMR spectrum reflected $\delta$ 's 23.71 and 25.72 belong to $2 \mathrm{C}$ of $\mathrm{CH} 3$ groups and three signals with $\delta$ 's $164.29,164.38,166.99$ ppm belong to the $3 \mathrm{C}$ of the aromatic ring (Fig.3b). 

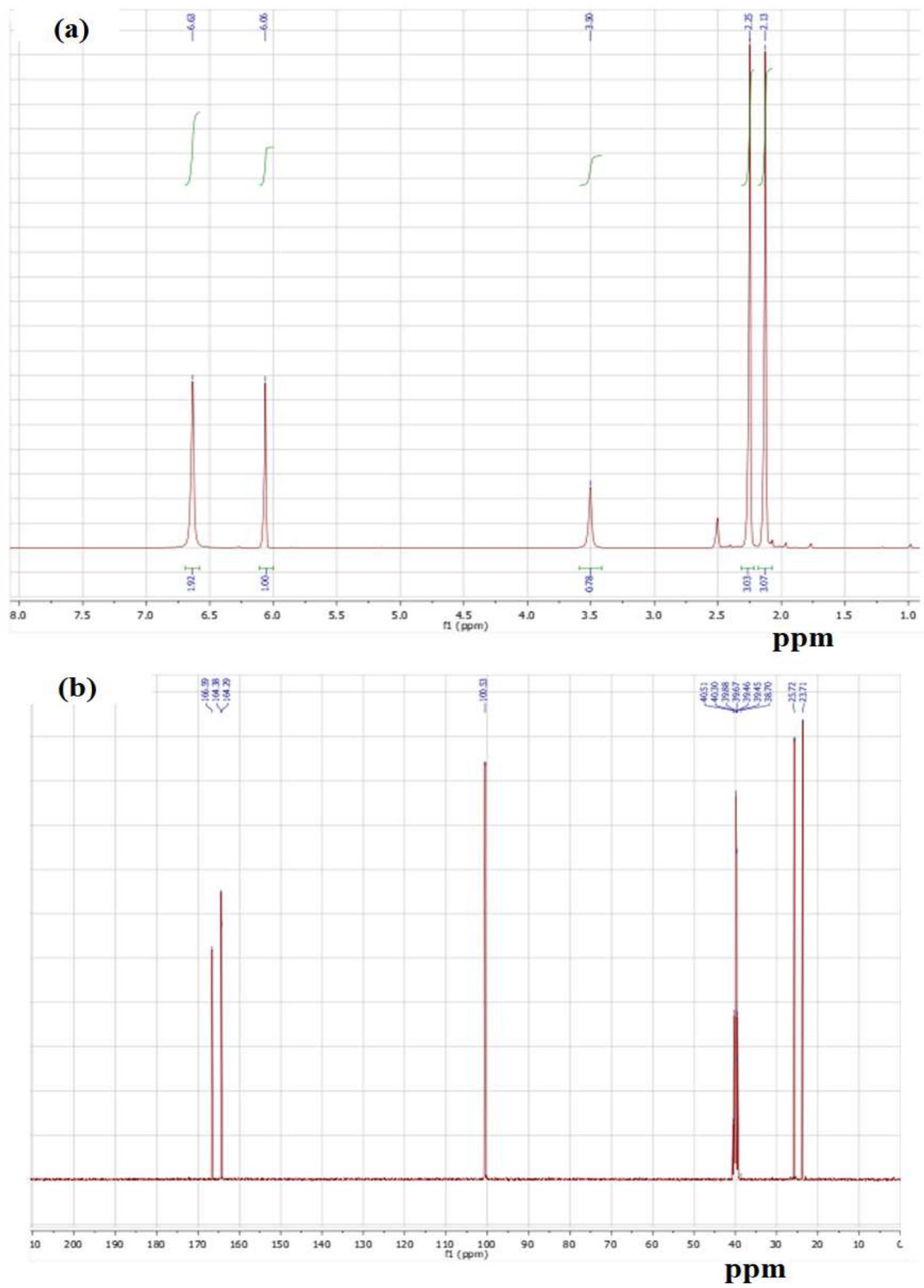

Fig. 3. (a) ${ }^{1} \mathrm{H}$ NMR and (b) ${ }^{13} \mathrm{C}$ NMR spectra in DMSO- $\mathrm{d}_{6}$ 


\subsection{XRD structural asnd packing analysis}

The structure of $\left[\mathrm{C}_{6} \mathrm{H}_{10} \mathrm{~N}_{3}\right]_{2}\left[\mathrm{CoCl}_{4}\right]$ complex is clarified in Fig.4a. Selected bond lengths and angles are listed in Table 2. The reflections were indexed in an orthorhombic lattice of dimensions $\mathrm{a}=15.38, \mathrm{~b}=17.98, \mathrm{c}=7.11 \AA$. The unit cell contains four tetrahedral units [CoCl4]2- and eight planar units 6-amino-2,4-dimethylpyrimidin-1-ium (r.m.s. of the fitted atoms to the least square plane is only 0.0194$)$, that is to say, four $\left(\mathrm{C}_{6} \mathrm{H}_{10} \mathrm{~N}_{3}\right)_{2} \mathrm{CoCl}_{4}$ formula units (Fig. 3). The final refinement converged to R1-factor of 3.58\%. Moreover, a regular tetrahedral geometry around the Co(II) center bound by 4 equivalent chlorine antions, with 2.25-2.29 $\AA \mathrm{Co}-\mathrm{Cl}$ average bond lengths and $105.23-113.76^{\circ} \mathrm{Cl}-\mathrm{Co}-\mathrm{Cl}$ average angles with slightly deviated from $109.5^{\circ}$ as ideal value [23-29].

The extinction conditions suggested centrosymmetry and space group Pnma. The structure contains anionic (-2) tetrachlorocobalt and 2 cationic (+1) 6-amino-2,4dimethylpyrimidin-1-ium units represented with ORTEP (Fig. 4a). 

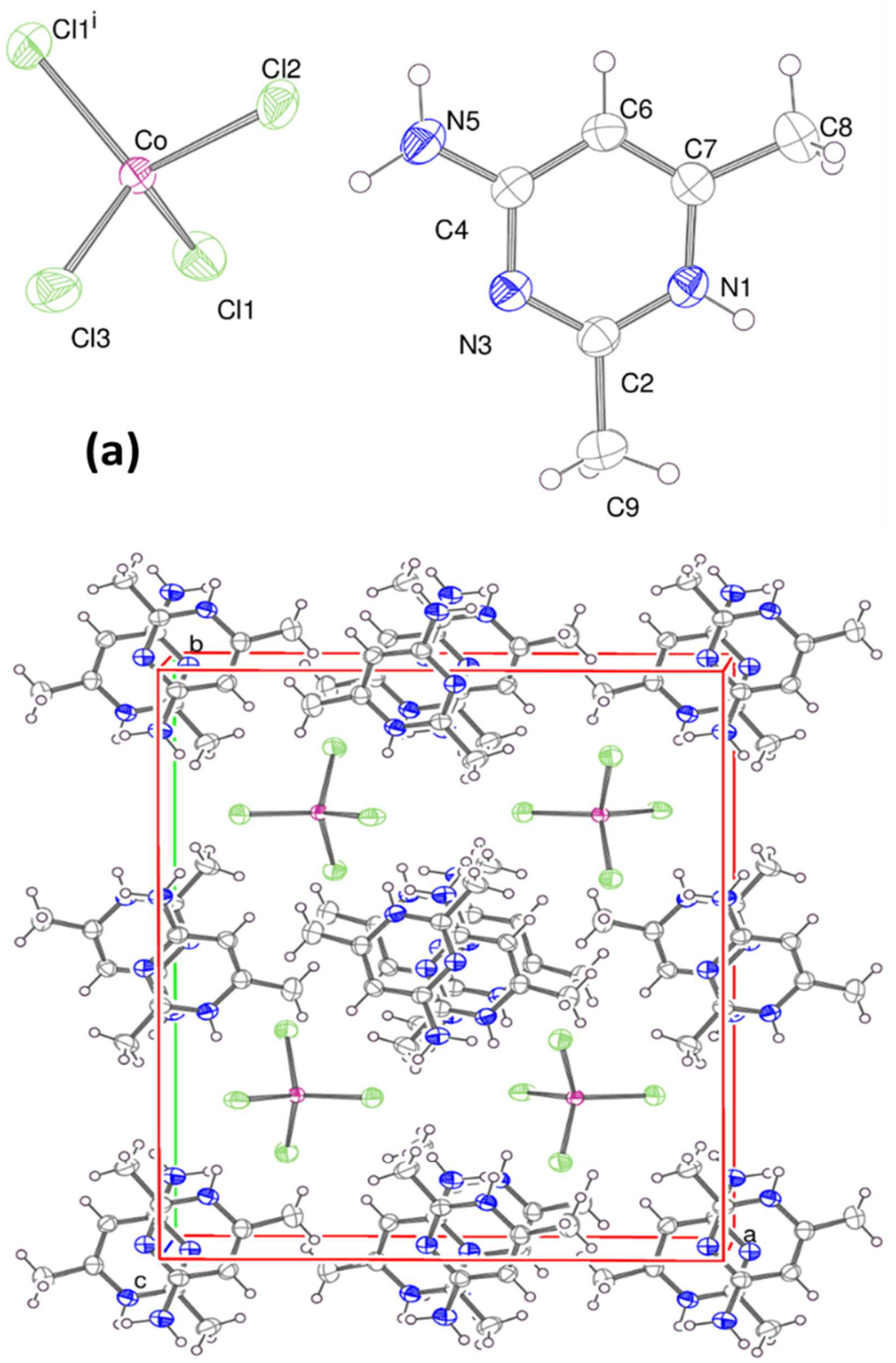

(b)

Fig. 4. ORTEP of $\left[\mathrm{C}_{6} \mathrm{H}_{10} \mathrm{~N}_{3}\right]_{2}\left[\mathrm{CoCl}_{4}\right]$ with two molecular units $\mathrm{CoCl}_{4}{ }^{2-} \& \mathrm{C}_{6} \mathrm{H}_{10} \mathrm{~N}_{3}{ }^{+}$and (b) the orthorhombic molecular packing lattice of $\mathrm{C}_{12} \mathrm{H}_{20} \mathrm{~N}_{6} \mathrm{CoCl}_{4}$ 
Table 2. Main bond lengths $[\AA]$ in $\mathrm{C}_{12} \mathrm{H}_{20} \mathrm{~N}_{6} \mathrm{CoCl}_{4}$

\begin{tabular}{ccccccccc}
\hline No. & \multicolumn{3}{l}{ Bond type } & $\AA$ & No. & \multicolumn{4}{c}{ Angle type } & $\mathbf{(})$ \\
\hline 1 & C11 & Co & 2.2544 & 1 & C11 & Co & Cl2 & 107.32 \\
2 & C12 & Co & 2.309 & 2 & C11 & Co & Cl3 & 109.58 \\
3 & C13 & Co & 2.283 & 3 & C11 & Co & C11 & 113.01 \\
4 & Co & C11 & 2.2544 & 4 & Cl2 & Co & Cl3 & 109.98 \\
5 & N1 & C2 & $1.346(3)$ & 5 & Cl2 & Co & Cl1 & 107.32 \\
6 & N1 & C7 & $1.361(3)$ & 6 & Cl3 & Co & C11 & 109.58 \\
7 & C2 & N3 & $1.313(3)$ & 7 & C2 & N1 & C7 & $122.2(2)$ \\
8 & C2 & C9 & $1.488(4)$ & 8 & N1 & C2 & N3 & $122.2(2)$ \\
9 & N5 & H5A & $0.98(5)$ & 9 & N1 & C2 & C9 & $117.6(2)$ \\
10 & N5 & C4 & $1.333(3)$ & 10 & N3 & C2 & C9 & $120.2(2)$ \\
11 & N5 & H5B & $0.89(3)$ & 11 & H5A & N5 & C4 & $121(2)$ \\
12 & N3 & C4 & $1.366(3)$ & 12 & H5A & N5 & H5B & $118(3)$ \\
13 & C8 & C7 & $1.485(4)$ & 13 & C4 & N5 & H5B & $121(2)$ \\
14 & C4 & C6 & $1.404(3)$ & 14 & C2 & N3 & C4 & $117.3(2)$ \\
15 & C7 & C6 & $1.351(3)$ & 15 & N5 & C4 & N3 & $116.6(2)$ \\
\hline
\end{tabular}

In the crystal lattice, four types of non-covalent bonds shorter than $3 \AA$ was detected by $\mathrm{XRD}$ measurements, since two polar $\mathrm{H}$ atoms together with three types of $\mathrm{N}$ atoms quoted in the complex structure, therefore, 4 types of H-bond linkages were recorded experimentally in the packed lattice of the desired complex as two types of $-\mathrm{HN}-\mathrm{H}$.....Cl with $2.307 \AA$ and -HN-H.....Cl..... H-NH with $2.463 \AA$ as illustrated in Fig.5a. one longer H-bonds were detected as -Nring-H.....Cl..... H-Nring with $2.385 \AA$ (Fig.5b). Furthermore, 2 longer H-bonds were recorded as -Cring-H.....Cl with $2.888 \AA$ (Fig.5c), no other interaction types were recorded. 

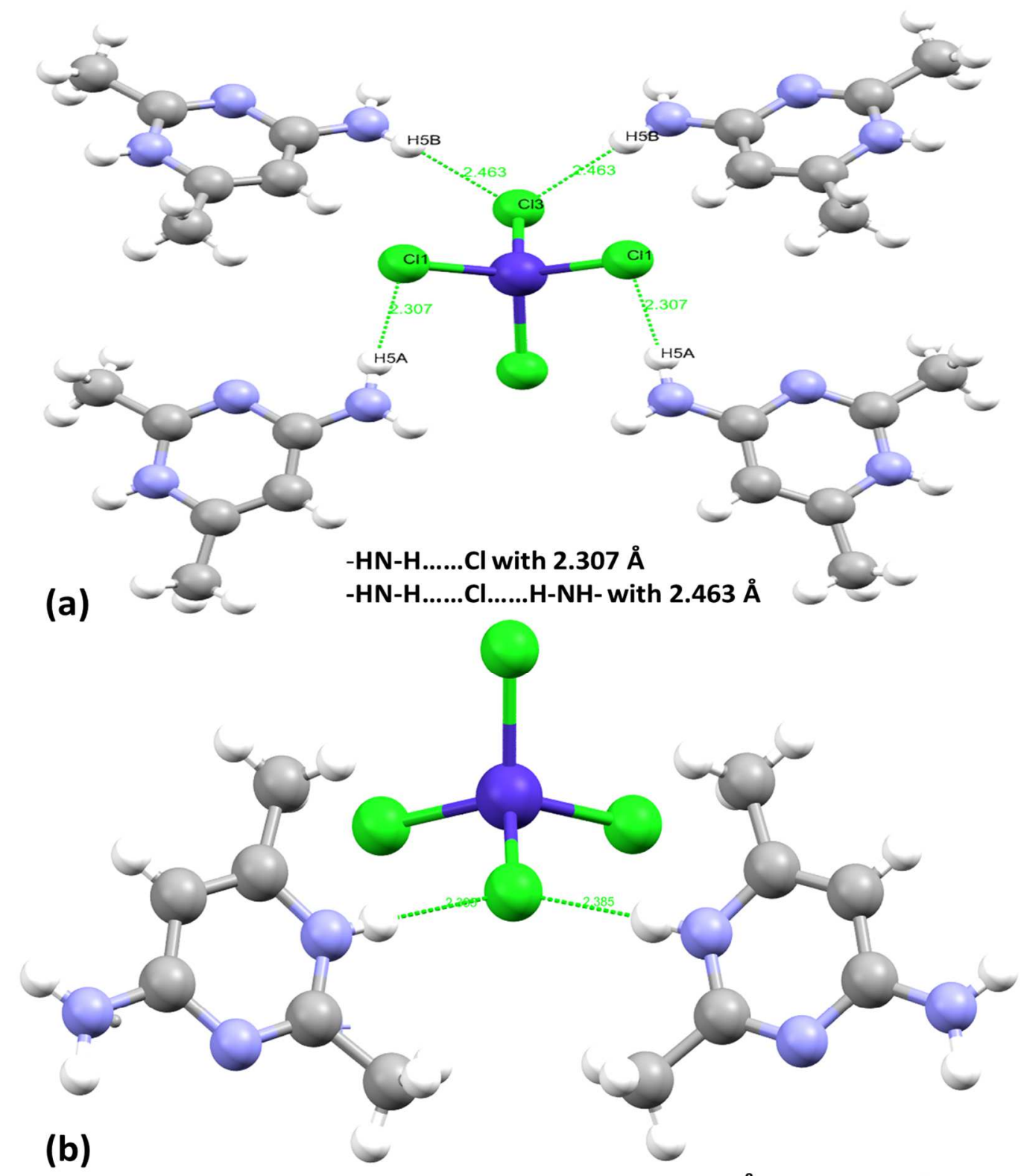

(b)

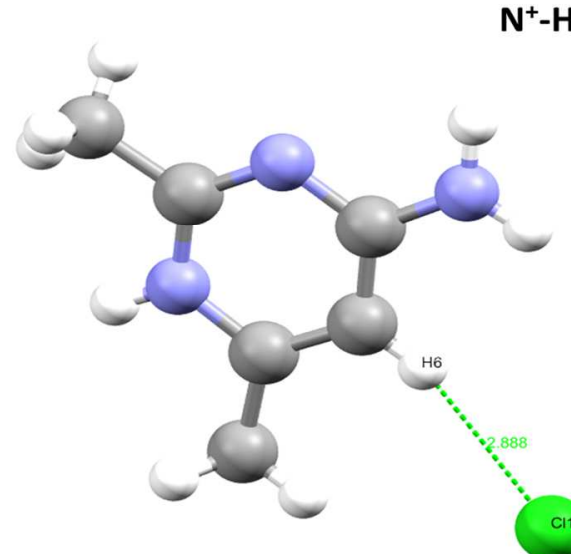

(c)

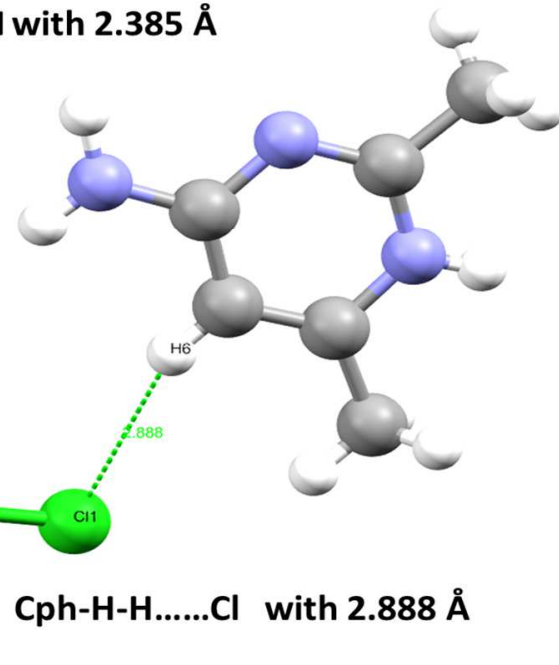

Fig. 5. H-bonds interaction: a) $-\mathrm{HN}-\mathrm{H} \ldots . . . \mathrm{Cl} \&-\mathrm{HN}-\mathrm{H}$.....Cl.... H-NH, b) $-\mathrm{N}_{\text {ring }}-\mathrm{H} . . . . \mathrm{Cl}$..... $\mathrm{H}-\mathrm{N}_{\text {ring }}$ and (c) $-\mathrm{C}_{\text {ring }}-\mathrm{H} \ldots . . \mathrm{Cl}$. 


\subsection{HSA}

To obtain additional information on the role played by intermolecular interactions within the crystal, a Hirshfeld surface analysis was performed [29-32]. The results are illustrated in Fig. 3 with representations of the Hirshfeld three dimensional surface mapped over the normalized $d_{\text {norm }}$ function (Fig.6) and shape index (Fig. 6b) established in the range 0.654 to 1.768 a. u.
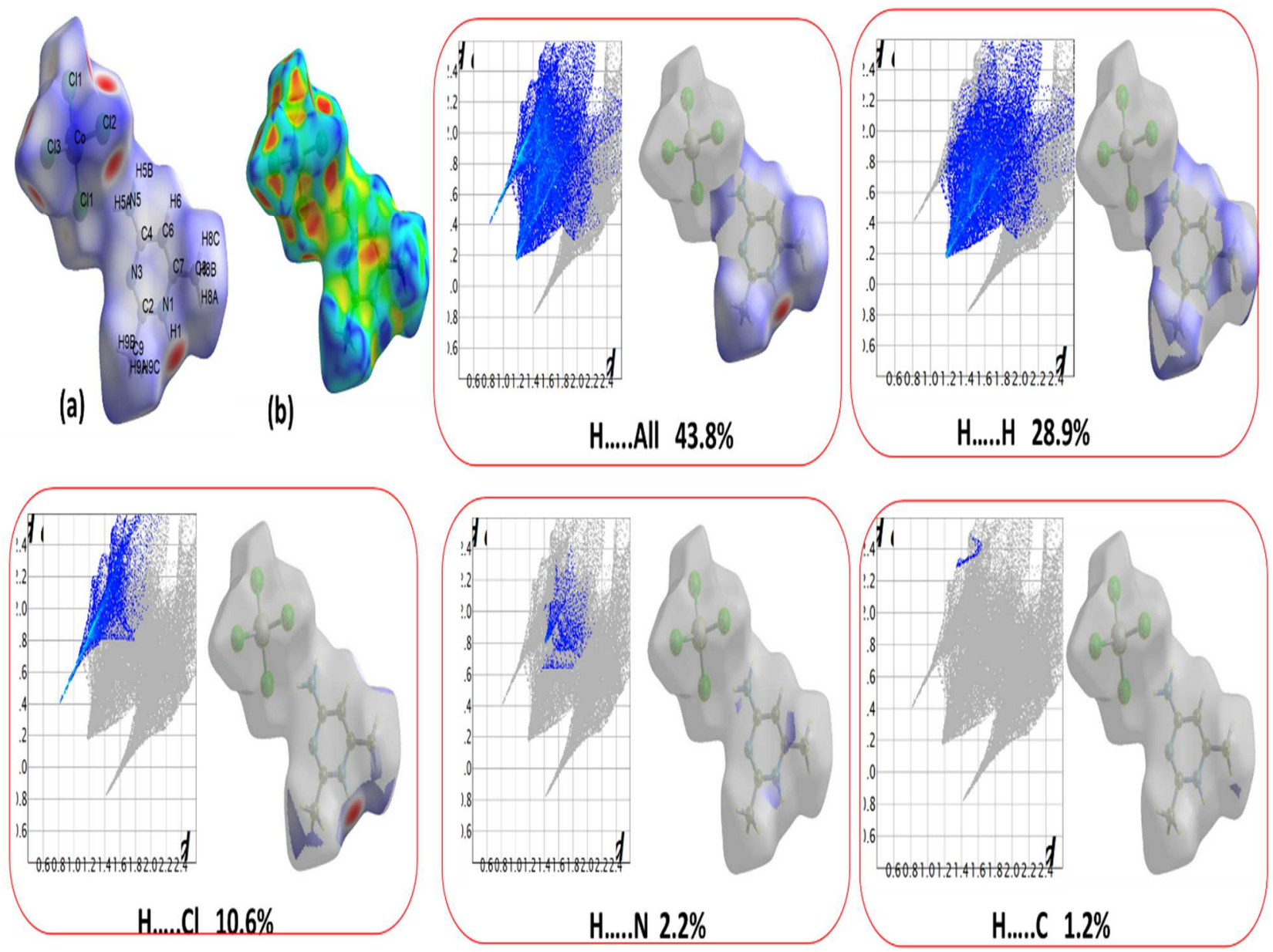

Fig.6. Hirshfeld surface mapped over $\mathrm{d}_{\text {norm }}$ (a), shape index (b) and inside/outside 2-D fingerprint plots (c).

The colors are related to the distance from the nearest neighbors and illustrate the strength of the intermolecular contacts. Large red zones are visible close to the chlorine atoms and the polar hydrogen atoms, six red spots were found on the surface computed for the molecular structure, they correspond to the presence of three short contacts or hydrogen type bonds. Two $\mathrm{N}-\mathrm{H}$......Cl bonds with a distance of $2.38 \AA$, two $\mathrm{NH}_{2} \ldots . . \mathrm{Cl}$ bonds with a distance of $2.31 \AA$ and two Cring-H....Cl with a distance of $3.17 \AA$ was counted in good agreement with packing in the crystal structure. 
The 2D fingerprint plots represented in Fig. $6 \mathrm{~b}$ has been built from the 3D Hirshfeld surface by considering inside and outside closest neighbors. These integrated views on intermolecular contacts are useful to visualize the contributions of either polar or non-polar interactions to the crystal packing forces. It is clear that the $\mathrm{H}$...H intermolecular contacts represent the larger part $(28.9 \%)$, which is due to the high number of $\mathrm{H}$-atoms and their spatial position in the molecule of the complex. In contrast, the H....N interactions are found with the lowest and almost zero ratios. The other atom...atom intermolecular contacts appear in the order of importance $\mathrm{H} \ldots . . \mathrm{Cl}(10.6 \%)>\mathrm{H} \ldots . \mathrm{N}(2.2 \%)>\mathrm{H} \ldots . . \mathrm{C}(1.2 \%)$.

\subsection{Catecholase studies}

\subsection{1. catecholase activity via $U V$-Vis study}

The catecholase activity of the complex was observed by treating $10^{-4} \mathrm{M}$ solution of complex with 100 equivalents of 3,5-DtBC $\left(10^{-2} \mathrm{M}\right)$ solution under aerobic fitness at room temperature in $\mathrm{MeOH}$, as seen in Scheme 2.
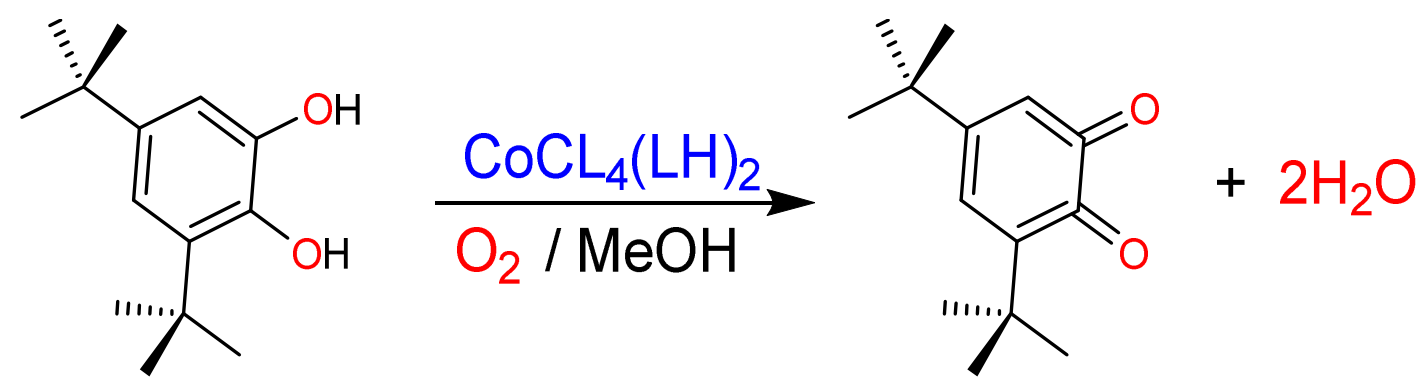

Scheme 2. Catalytic oxidation of 3.5-DtBC to 3,5-DtBQ.

The above oxidation process was monitored by UV-vis., the Spectrophotometric data have been noted by generating absorbance versus wavelength $(\lambda=400 \mathrm{~nm}$ scan) plots at a regular time intervals of $5 \mathrm{~min}$ in the range 325-625 $\mathrm{nm}$ (Fig.7a). The 3,5-DtBQ product band appeared at $400 \mathrm{~nm}$ which graduately increases in intensity by time reflected the completeness of the reaction, No absorbance at this band was observed in the absent of $\left[\mathrm{C}_{6} \mathrm{H}_{10} \mathrm{~N}_{3}\right]_{2}\left[\mathrm{CoCl}_{4}\right]$ or even in the presence of $\mathrm{CoCl}_{2} .6 \mathrm{H}_{2} \mathrm{O}$ using the 3,5-DtBC substrate (Fig. 7b) , therefore, it is clearly observed that $\left[\mathrm{C}_{6} \mathrm{H}_{10} \mathrm{~N}_{3}\right]_{2}\left[\mathrm{CoCl}_{4}\right]$ acted as a mild condition catalyst in absence of complex as indicated by the black curve. It clearly appears that the complex drives the oxidation reaction of 3,5-DtBC to 3,5-DtBQ under mild conditions. 

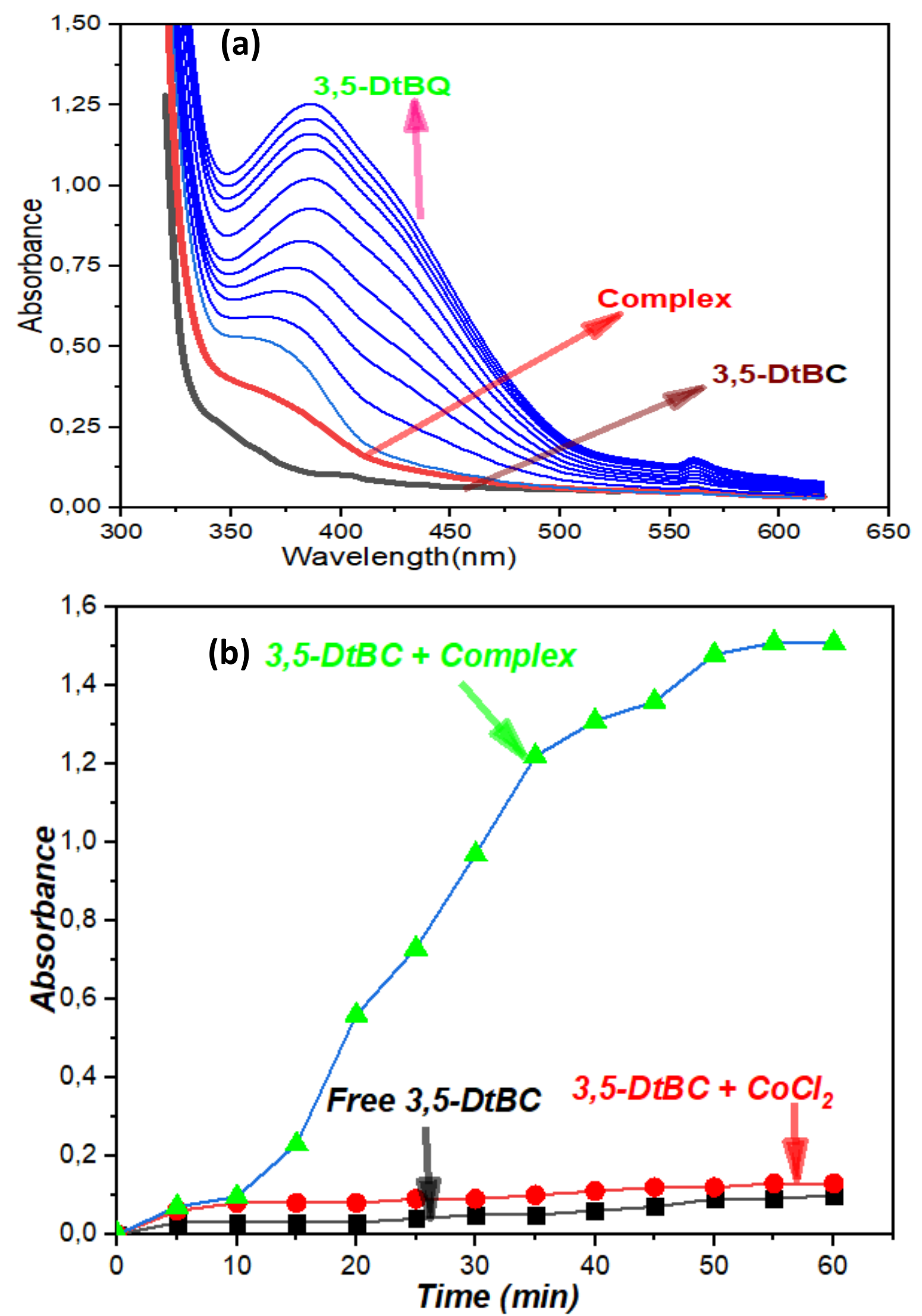

Fig. 7. (a) Wavelength scan and (b) Abs. vs. time (at $\lambda=400 \mathrm{~nm}$ ) plots for the oxidation of 3,5-DtBC to 3,5-DtBQ in the absence and presence of the $\left[\mathrm{C}_{6} \mathrm{H}_{10} \mathrm{~N}_{3}\right]_{2}\left[\mathrm{CoCl}_{4}\right]$ complex. 


\subsection{Kinetic study}

A kinetic approach based on the Michaelis-Menten procedure was applied and the results were deduced from the non-linear Michaelis-Menten hyperbolic plots. Control experiments were conducted for the Cobalt (II) chloride salt and for the ligand (L) to identify any singular influences on the oxidation of 3,5-DtBC [33-36]. The concentration of the complex was (10-3 mol.L-1) and the 3,5-DtBC concentration was varied in the range 5, 10, 20, 40, 60 and 80 equivalents. The progression of absorbance of 3,5-DtBQ at $400 \mathrm{~nm}$ was controlled for the first 5 minutes of the reaction time, and the linear correlation for the prime rates and the substrate concentration was collected. The rate versus concentration data for the substrate was examined on the basis of Michaelis-Menten approach of enzymatic kinetics to get the Lineweaver-Burk (double reciprocal) plot as well as the values of the various kinetic parameters. The kinetic study for the complex shows that applying the Michaelis-Menten model to determine kinetic parameters leads to Vmax speed of $16.82 \mu \mathrm{M}$.L-1.min-1 and kinetic parameters $\mathrm{Km}$ of $0.12 \mathrm{M}$ and kcat of $84.08 \mathrm{M}-1 . \mathrm{h}-1$. As clearly shown on the graphic representation of rates (V) as a function of the substrate concentration progression (Fig. 8), the reaction rate increases immediately and reaches its maximum for about 10 equivalents of 3,5DtBC .
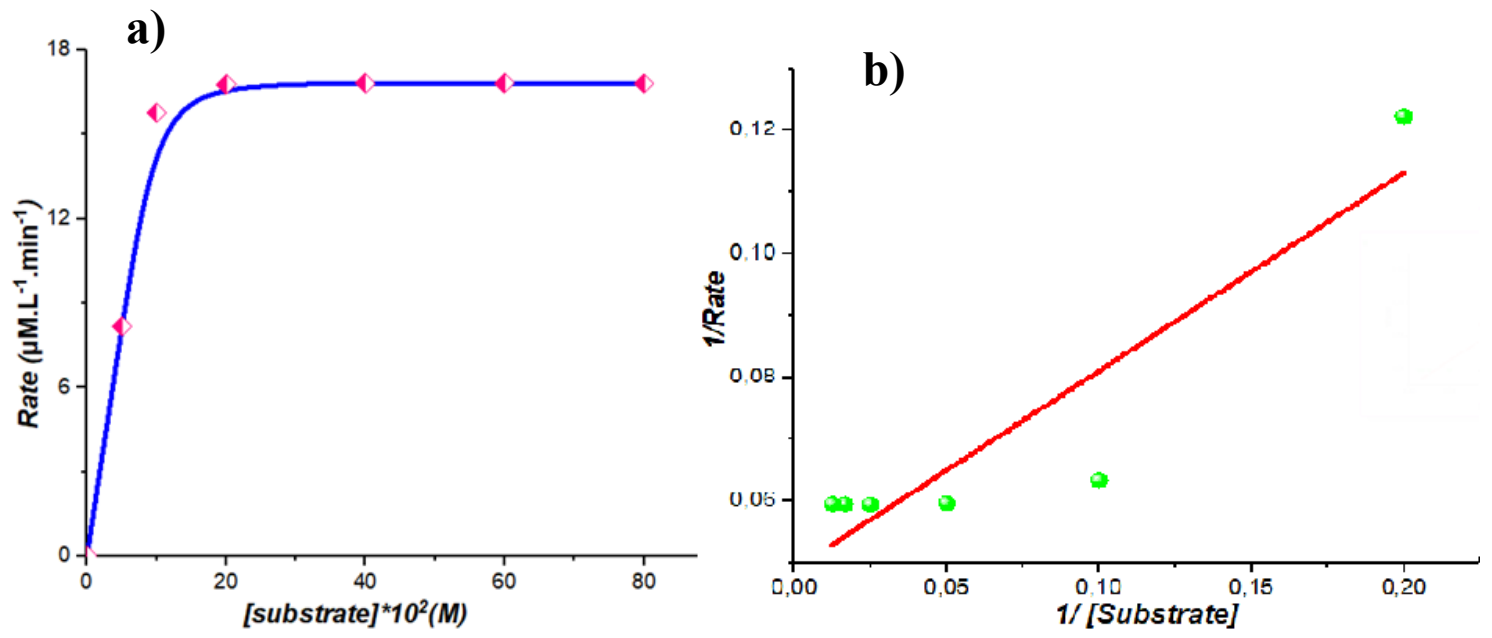

Fig. 8. a) Enzymatic Michaelis-Menten Kinitic plot (rate vs. [substrate]) and b) LineweaverBurk plot (1/rate vs.1/[substrate] for the complex in $\mathrm{MeOH}$.

Table 4. A comparison of $\mathrm{V}_{\max }, \mathrm{K}_{\mathrm{M}}$ and $\mathrm{k}_{\mathrm{cat}}$ values reported in the litterature for cobalt complexes in the oxidation of 3,5-DtBC to 3,5-DtBQ

\begin{tabular}{llllll}
\hline Complex \& ref. & $\mathrm{V}_{\max }$ & $\mathrm{K}_{\mathrm{M}}$ & $\mathrm{k}_{\text {cat }}$ & $\mathrm{k}_{\text {cat }} / \mathrm{K}_{\mathrm{M}}$ & Solvent \\
& $\left(\mathrm{M} \cdot \mathrm{L}^{-1} \cdot \mathrm{min}^{-1}\right)$ & $(\mathrm{M})$ & $\left(\mathrm{h}^{-1}\right)$ & $\mathrm{M}^{-1} \cdot \mathrm{h}^{-1}$ & \\
\hline
\end{tabular}




\begin{tabular}{llllll}
\hline $\mathrm{CoCl}_{4}(\mathrm{LH})_{2}$ & $16.82 \times 10^{-6}$ & $12.103 \times 10^{-2}$ & 10.09 & 84.08 & $\mathrm{MeOH}$ \\
{$[26]$} & $18.91 \times 10^{-6}$ & $15.7 \times 10^{-4}$ & 45.38 & $28.9 \times 10^{3}$ & $\mathrm{MeOH}$ \\
{$[27]$} & $3.40 \times 10^{-4}$ & $1.89 \times 10^{-4}$ & 11.2 & $59.25 \times 10^{3}$ & $\mathrm{DMF}$ \\
{$[28]$} & $1.5 \times 10^{-6}$ & $24.7 \times 10^{-4}$ & 0.9 & 364 & $\mathrm{MeOH}$ \\
{$[28]$} & $11.7 \times 10^{-6}$ & $27.7 \times 10^{-4}$ & 7.02 & 2534 & $\mathrm{MeOH}$ \\
{$[26]$} & $7.14 \times 10^{-6}$ & $24.5 \times 10^{-4}$ & 42.9 & 17510 & $\mathrm{THF}$ \\
{$[28]$} & $1.9 \times 10^{-6}$ & $24.7 \times 10^{-4}$ & 1.14 & 461 & $\mathrm{CH}_{3} \mathrm{CN}$ \\
\hline
\end{tabular}

To properly establish the catalytic activity of the 3,5-DtBC on the production kinetics of 3,5DtBQ, a volume of $0.15 \mathrm{~mL}$ of complex $\left(1 \times 10^{-4} \mathrm{M}\right)$ dissolved in methanol was added to $2 \mathrm{ml}$ of 3,5-DtBC $\left(1 \times 10^{-1} \mathrm{M}\right)$, and then the spectral variations were quantified using the progression of the absorbance band characteristic of the 3,5-DtB-quinone registered every $5 \mathrm{~min}$. The kinetic experiments were realized at room temperature.

\section{Conclusion}

During this work, we synthesized a $\left[\mathrm{C}_{6} \mathrm{H}_{10} \mathrm{~N}_{3}\right]_{2}\left[\mathrm{CoCl}_{4}\right]$ complex designed by 6-amino-2,4dimethylpyrimidin-1-ium ligand and $\mathrm{CoCl}_{2} \cdot 6 \mathrm{H}_{2} \mathrm{O}$ salt. The complex is described by various spectroscopic techniques as ${ }^{1} \mathrm{H} \&{ }^{13} \mathrm{C}$ NMR, UV-vis., FT-IR, CHN-EA and HSA. The structure of $\left[\mathrm{C}_{12} \mathrm{H}_{20} \mathbf{N}_{6} \mathrm{CoCl}_{4}\right]$ was proved by XRD-diffraction. The XRD reflected the tetrachloridecobaltate(II) anion as tetrahedral geometry around the cobalt center. The HSA and XRD analysis supported the presence of many H-bond like of -HN-H....Cl with $2.307 \AA$ and $-\mathrm{HN}-\mathrm{H} . . . . \mathrm{Cl} \ldots . . \mathrm{H}-\mathrm{NH}$ with $2.463 \AA,-\mathrm{N}_{\text {ring }}-\mathrm{H} \ldots . . . \mathrm{Cl} \ldots . . \mathrm{H}-\mathrm{N}_{\text {ring }}$ with $2.385 \AA$ and $-\mathrm{C}_{\text {ring- }}$ H.....Cl with $2.888 \AA$ distances.

The complex displays a good catalytic behavior, under ambient conditions, estimate to the oxidation of 3,5-D $t \mathrm{BC}$ to 3,5-D $t \mathrm{BQ}$ using atmospheric oxygen as oxidant in methanol. Overall the catalytic activity of the $\left[\mathrm{C}_{6} \mathrm{H}_{10} \mathrm{~N}_{3}\right]_{2}\left[\mathrm{CoCl}_{4}\right]$ complex is found very similar to that of some other cobalt complexes.

\section{References}

[1] C. R. Kagan, D. B. Mitzi, C. D. Dimitrakopoulos, Transistors, Sci. 286 (1999) 945.

[2] J. L. Knutson, J. D. Martin, D. B. Mitzi, Inorg. Chem. 44 (2005) 4699.

[3] T. Sekine, T. Okuno, K. Awaga, Mol. Cryst. Liq. Cryst. 279 (1996) 65. 
[4] C. Aruta, F. Licci, A. Zappettini, F. Bolzoni, F. Rastelli, P. Ferro, T. Besagni, Appl. Phys. A 81 (2005) 963.

[5] J-C. Chang, W-Y Ho, I-W Sun, Y-K Chou, H-H Hsieh, T-Y Wu, , Polyhedron 30 (2011) 497.

[6] K. Chondroudis, D. B. Mitzi, , J. Chem. Mater. 11 (1999) 3028.

[7] C.J. Adams, A.L. Gillon, M. Lusi, A.G. Orpen, CrystEngComm 12 (2010) 4403.

[8] I. Baccar, F. Issaoui, F. Zouari, M. Hussein, E. Dhahri, M.A. Valente, Solid State Commun. 150 (2010) 2005-2010.

[9] C. Decaroli, A.M. Arevalo- Lopez, C.H. Woodall, E.E. Rodriguez, c J.P. Attfield, S.F.

Parkerd, C. Stock, Acta Crystallogr. B71 (2015).

[10] J. Falbe, Carbon Monoxide in Organic Synthesis, vol 10, Springer Science \& Business Media, 2013.

[11] F. Hebrard, P. Kalck, Chem. Rev. 109 (9) (2009) 4272.

[12] R.F. Heck, D.S. Breslow, J. Am. Chem. Soc. 83 (19) (1961) 4023.

[13] G.O. Spessard, G.L. Miessler, Organometallic Chemistry, 2009.

[14] C. Brown, G. Wilkinson, Inorg. Phys. Theor. (1970) 2753.

[15] R.K. Hocking, T.W. Hambley, Organometallics 26 (11) (2007) 2815.

[16] M. F. Kamaruzaman, Y. H. Taufiq-Yap', D. Derawi, Biomass and Bioenergy 134 (2020) 105476.

[17] T. Deelen, H.Yoshida, R. Oord, J. Zečević, B.M. Weckhuysen, K.P.de Jong, Appl. Cat. A: General, 593 (2020) 117441.

[18] L. Li, JingXu, Appl. Surf. Sci. 505 (2020) 143937.

[19] S. K. Wolff, D. J. Grimwood, J. J. McKinnon, D. Jayatilaka, and M. A. Spackman (2007).

Crystal explorer 2.1. University of Western Australia, Perth.

[20] Bruker, APEX3. Version 2017.3-0, Bruker AXS, Inc., Madison, Wisconsin, USA, 2017

[21] G. M. Sheldrick, Acta Crystallogr., Sect. A: Fundam. Crystallogr., 71 (2015) 3.

[22] G. M. Sheldrick, Acta Crystallogr., Sect. C: Cryst. Struct. Commun., 71 (2015) 3.

[23] M. Maha, D. E. Janzen, R. Mohamed, S. Wajda, J Supercond Nov Magn, 29 (2016) 1573.

[24] F. Issaoui, W. Amamou, M. Bekri, F. Zouari, E. Dhahri, M.A. Valente, J. Mol. Struc. 1189 (2019) 175.

[25] M. Tahenti, S. Gatfaoui, N. Issaoui, T. Roisnel, H. Marouani, J. Mol. Struc., 1207 (2020) 127781 .

[26] O. Moussa, H. Chebbi, M. Zid, J. Mol. Struc., 1180 (2020) 72.

[27] A. Tounsi, S. Elleuch, B. Hamdi, R. Zouari, A.Salah, J. Mol. Struc., 1141 (2019) 512. 
[28] R. Debabis, W. Amamou, N. Chniba-Boudjada, F. Zouari, J. Phys. Chem. Solids, 124 (2019) 296.

[29] A. Titi, T. Shiga, H. Oshio, R. Touzani, B. Hammouti, M. Mouslim, I. Warad, J. Mol. Struc. 1199 (2020) 126995.

[30] A. Barakat, M.S. Islam, A.M. Al-Majid, H.A. Ghabbour, S. Atef, A. Zarrouk, I. Warad, J. Theor. Comput. Chem. 17 (2018) 1850005.

[31] I. Warad, F. F. Awwadi, B. Abd Al-Ghani, A Sawafta, N. Shivalingegowda, N. K. Lokanath, M.S. Mubarak, T. Ben Hadda, A. Zarrouk, F. Al-Rimawi, A. B. Odeh, S. A. Barghouthi, Ultrasonics Sonochem. 48 (2018) 1.

[32] M. Aouad, M. Messali, N. Rezki, M. A. Said, D. Lentz, L. Zubaydi, I. Warad, J. Mol. Struc. 1180 (2019) 455.

[33] P. Chakraborty, S. Mohanta, Inorg. Chim. Acta 435 (2015) 38.

[34] S. Majumder, S. Mondal, P. Lemoine and S. Mohanta, Dalton Trans., 42 (2013) 4561. [35] J.-H. Qiu, Z.-R. Liao, X.-G. Meng, L. Zhu, Z.-M. Wang and K.-B. Yu, Polyhedron, $24(2005) 1617$.

[36] A. Banerjee, A. Guha, J. Adhikary, A. Khan, K. Manna, S. Dey, E. Zangrando and D. Das, Polyhedron, 60 (2013) 102. 